\title{
Genome sequence of Coxiella burnetii strain Namibia
}

\author{
Mathias C Walter ${ }^{1,2 \dagger}$, Caroline Öhrman ${ }^{3 \dagger}$, Kerstin Myrtennäs ${ }^{3}$, Andreas Sjödin $^{3}$, Mona Byström $^{3}$, Pär Larsson ${ }^{3}$, \\ Anna Macellaro ${ }^{3}$, Mats Forsman ${ }^{3 \dagger}$ and Dimitrios Frangoulidis ${ }^{4^{*}+}$
}

\begin{abstract}
We present the whole genome sequence and annotation of the Coxiella burnetii strain Namibia. This strain was isolated from an aborting goat in 1991 in Windhoek, Namibia. The plasmid type QpRS was confirmed in our work. Further genomic typing placed the strain into a unique genomic group. The genome sequence is 2,101,438 bp long and contains 1,979 protein-coding and 51 RNA genes, including one rRNA operon. To overcome the poor yield from cell culture systems, an additional DNA enrichment with whole genome amplification (WGA) methods was applied. We describe a bioinformatics pipeline for improved genome assembly including several filters with a special focus on WGA characteristics.
\end{abstract}

Keywords: Coxiella burnetii, Q fever, Whole genome sequencing, Next generation sequencing (NGS), Assembly, Annotation, Whole genome amplification

\section{Introduction}

Creation of whole genome information of Coxiella burnetii is a cumbersome procedure. All work with living strains of C. burnetii is impaired by the necessity to handle strains under Biosafety 3 conditions. The enrichment of this bacterium is normally done in animal derived cell culture systems with a peak of replication after 5 to 7 days of growth. The overall yield of bacteria, however, is less than that obtained by "classical" growth of bacteria on artificial media. Alternative enrichment methods, like animal inoculation and cultivation in hen eggs, present various problems and risks in processing, thus are not in common use for C. burnetii. The required amount and quality of DNA for whole genome sequencing of $C$. burnetii is not easily obtained by cell culture. Furthermore, DNA isolation is not always successful and not all DNA preparations are of a quality suitable for sequencing purposes. To overcome these problems, WGA techniques may present an attractive alternative for generation of C. burnetii DNA [1]. Such assays possess an impressive power to amplify traces of DNA to a satisfactory quantity. However, a careful evaluation with the species of interest is mandatory to judge

\footnotetext{
* Correspondence: dimitriosfrangoulidis@bundeswehr.org

${ }^{\dagger}$ Equal contributors

${ }^{4}$ Bundeswehr Institute of Microbiology (BwIM), Munich, Germany

Full list of author information is available at the end of the article
}

its suitability. Repeat structures and insertions sequences (IS) in particular might influence the quality of amplification. The Coxiella genome shows IS elements with sometimes more than 100 copies [2], stressing the importance of thorough evaluation of WGA techniques. We chose a special variant of WGA, the MDA method, that has been successful applied $[3,4]$ and is commercially available from different companies (RepliG, Qiagen, Hilden, Germany and GenomiPhi, GE Healthcare, Freiburg, Germany) [5]. Very recently the RepliG kit was used with Coxiella DNA and evaluated at 20 selected loci [6].

In this study, we describe a method for obtaining high quality DNA from Coxiella suitable for whole genome sequencing. We also evaluate the utility of WGA for Coxiella whole genome sequencing and WGA induced demands on downstream bioinformatics processing of sequence data, especially for genome assembly and finishing. The whole genome sequence presented here is the first of a C. burnetii strain originating from the African continent and will increase the genomic knowledge for this region.

\section{Organism information}

C. burnetii is the causative pathogen of the zoonotic disease $\mathrm{Q}$ fever, which has a worldwide distribution with the only exceptions of New Zealand and Antarctica. The bacterium was first independently described and isolated 
in Australia and the United States of America in 1937 $[7,8]$. C. burnetii is an obligately intracellular, small, Gram-negative, non-motile, pleomorphic, coccobacillary bacterium $(0.2-0.4 \mu \mathrm{m} \times 0.4-1 \mu \mathrm{m})$. Atypically, its Gram-negative membrane cannot be stained using Gram techniques, but can be visualized by the Gimenez method [9].

As a result of phenotypic similarities, the genus Coxiella was initially placed within the Rickettsiales order. More recent phylogenetic investigations, mainly based on $16 \mathrm{~S}$ rRNA gene sequence analysis, resulted in re-classification of the Coxiella genus into the Legionellales order [10]. Within the Proteobacteria, they belong to the family Coxiellaceae [11] (Table 1).

In its development cycle, $C$. burnetii generates both large (LCV) and small cell variants $(\mathrm{SCV})$. The latter are more environmentally stable and present the infectious particles incorporated by different hosts. After uptake by macrophages, the LCV is formed within phagolysosomes.

The bacterium exists in two antigenic phases, which are analogous to the smooth (phase I) and rough (phase II) LPS forms seen among the Enterobacteriaceae. Phase I bacteria can be observed during natural infections of humans and animals, whereas bacteria in phase II, which are mainly non-virulent, evolve after several passages in embryonated hen eggs or cell cultures. Transitions between both forms have been described [12].

C. burnetii has a large reservoir of hosts including many wild and domestic mammals, birds, reptiles, fish and even arthropods such as ticks and flies. Due to its transmission by inhalation, low infectious dose, high stability, and prior weaponization, C. burnetii is classified as a category $\mathrm{B}$ agent of bioterrorism by the Centers for Disease Control (CDC, Atlanta, USA) [11]. Epidemiological studies have demonstrated that the most frequent route of human C. burnetii infections is via domestic ruminants such as sheep, goats, or cattle. These animals may be chronically infected without showing any clinical symptoms and shed vast numbers of the bacterium into the environment, mainly during parturition. Counts of C. burnetii in excess of $10^{9}$ bacteria per gram have been recorded in placental tissue, but in other birth-associated products such as amniotic fluids or in milk, high quantities of $C$. burnetii may also be present. Particularly high counts have been obtained from tick feces with reports of $10^{10}$ living organisms per gram [13]. Despite this, ticks do not appear to be a significant risk factor for acquisition of human infection [14].

The organism is a highly infectious agent, with experimental estimates suggesting an infectious dose of less than 10 organisms for manifestation of an infection [15]. Furthermore, coxiellae are highly resistant to both heat and desiccation, ubiquitously available, and their aerosolized state is infectious over several kilometers $[16,17]$.
C. burnetii strains appear with five different plasmid types, four different plasmids (QpH1, QpRS, QpDV, and QpDG) and one type with a chromosomal plasmidhomologous sequence [18-22]. The characterization of these plasmids led to a classification into five genomic groups. Some plasmid types could be associated with various geographic regions. A formerly hypothesized correlation of these genomic groups with virulence or clinical manifestation could not be confirmed in later studies [23].

Because of the highly infectious nature of C. burnetii, cultivation should not be attempted outside adequate BSL 3 laboratories. Even with these, isolation is a difficult and very time-consuming procedure. Moreover, culture is not as sensitive as other methods such as detection of Coxiella-specific DNA. Viable cultures are however necessary for further scientific investigations, thus remain a research if not diagnostic priority. As C. burnetii is a strict intracellular bacterium, options for cultivation were previously restricted to the use of guinea pigs, mice and embryonated eggs [24]. These have now been largely abandoned for safety reasons. Instead, the less hazardous in vitro use of cell cultures such as human embryonic lung fibroblasts (HEL cells); embryonic epithelial kidney cells like the BGM cells; Vero-Cells or L929 have become the mainstay for cultivation work [25]. The culture of C. burnetii may require several weeks prior to the appearance of intracellular vacuoles, the hallmark of successful infection (see Figure 1). Although C. burnetii is an obligate intracellular pathogen, that needs living cells for cultivation, Omsland et al. recently published the development of a complex nutrient medium that supported substantial growth of C. burnetii in a $2.5 \%$ oxygen environment under axenic (host cell-free) conditions [26].

The strain Namibia was first described in 1991, when isolated from an aborting goat. It shows the QpRS

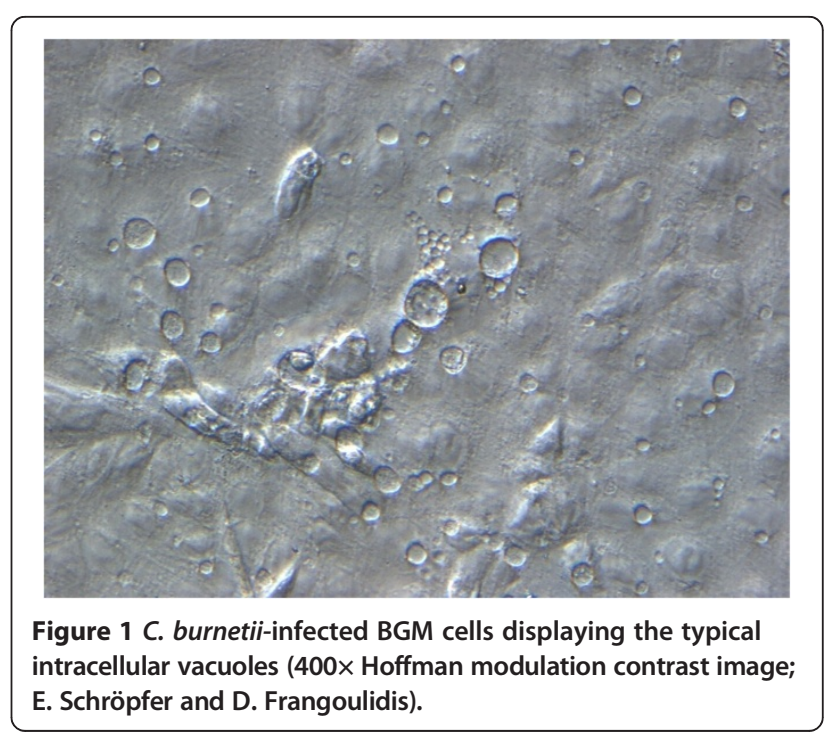


plasmid type, which is rarely observed, compared to the predominant $\mathrm{QpH} 1$ variant. Using established molecular typing methods, the strain shows the sequence type (ST) 30 (Multispacer Sequence Typing = MST) and the Multiple Loci Variable number of tandem repeat (VNTR) analysis (MLVA) genotype D16. Based on these typing data, the nearest known geographic neighbor is a strain from Morocco, which belongs also to the D cluster (D6). However, the Morocco strain has a very different repeat pattern and currently no whole genome sequencing data is available to determine its phylogenetic relationship. The phylogenetic position of strain Namibia is show in Figure 2.

\section{Genome sequencing information} Genome project history

The organism was initially selected for the development of a rapid Melt-MAMA SNP typing [46] on the basis of its economic importance in livestock farming and public health as well as its geographical location. It is the first known sequenced isolate from the African continent having the QpRS plasmid. The genome was sequenced in 2012 and the pre-filtered sequencing data was deposited at the NCBI Short Read Archive (SRA) under the accession SRX270891 and made public in September 2013. The assembly and annotation version was deposited at DDBJ/EMBL/GenBank with the accession numbers CP007555 and CP007556 and locus tag CBNA. Table 2 presents the project information and its association with MIGS version 2.0 compliance [33].

\section{Growth conditions and DNA isolation}

BGM cells (Flow Laboratories, Rockville, MD, USA) were grown in Eagles minimal essential medium (MEM) supplemented with Earls salts, $2 \mathrm{mM}$ L-glutamax, 5\% Fetal Calf Serum (FCS), 1\% Non-Essential Amino acids (NEA) and $0.2 \%$ sodium bicarbonate (Sigma-Aldrich, St Louis, MO, USA). Confluent cell layers were infected with bacteria and incubated at $37^{\circ} \mathrm{C}$. Fresh media was added after $20-24 \mathrm{~h}$. To enhance vacuole formation, the infected confluent BGM cells were divided using trypsin. C. burnetii cells were collected from the medium of actively growing cultures after 7-8 days by differential centrifugation. An initial centrifugation step to remove cell debris was performed at $500 \times \mathrm{g}(1,500 \mathrm{rpm})$ for 5 minutes at $4^{\circ} \mathrm{C}$, followed by a second centrifugation step to collect the bacteria at $2,550 \times \mathrm{g}$ $(3,500 \mathrm{rpm})$ for one hour at $4^{\circ} \mathrm{C}$.

The bacteria from confluently growing cell cultures were harvested by differential centrifugation as described above. The bacteria were washed twice in PBS. The bacterial pellet was then resuspended in $50 \mathrm{mM}$ Tris $(\mathrm{pH} 7.8)$ and mixed with $10 \mathrm{mM} \mathrm{MgSO}_{4}$ solution containing $20 \mu \mathrm{g}$ DNase (Ambion, Life Technologies, Carlsbad, CA, USA). The resulting suspension was incubated at $37^{\circ} \mathrm{C}$ for $30 \mathrm{mi}$ nutes. $0.5 \%$ SDS and $50 \mu \mathrm{g} / \mathrm{ml}$ proteinase $\mathrm{K}$ solution were then added and the sample was incubated at $56^{\circ} \mathrm{C}$ for one

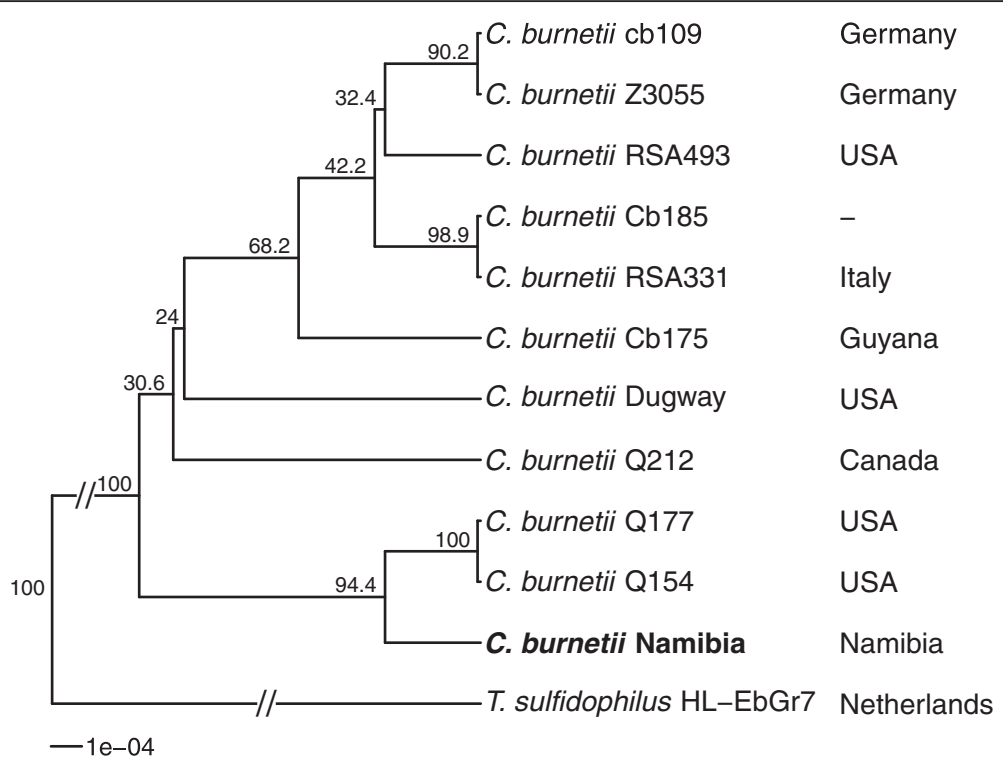

Figure 2 Phylogenetic tree highlighting the position of $C$. burnetii strain Namibia (shown in bold) relative to the other $C$. burnetii strains with whole genome sequences available. The average linkage (UPGMA) tree was inferred from 5,010 aligned positions of conserved blocks (determined using Gblocks [27]) of the rRNA operon sequences using the Juxes \& Cantor model, calculated with the R packages ape [28] and phangorn [29]. Bootstrap values (expressed as percentages of 1,000 replicates) are shown at branch points. The closest related species based on a BLAST [30] search against bacterial genomes of the National Center for Biotechnology Information (NCBI) non-redundant (nr) database [31] using the rRNA operon sequence is currently Thioalkalivibrio sulfidophilus HL-EbGr7 [32], a species commonly isolated from soda lakes, and was used as outgroup to root the tree. 
Table 1 Classification and general features of $C$. burnetii strain Namibia according to the MIGS recommendations [33]

\begin{tabular}{|c|c|c|c|}
\hline MIGS ID & Property & Term & $\begin{array}{l}\text { Evidence } \\
\text { code }^{a}\end{array}$ \\
\hline & Classification & Domain: Bacteria & TAS [34] \\
\hline & & Phylum: Proteobacteria & TAS [35] \\
\hline & & Class: Gammaproteobacteria & TAS $[36,37]$ \\
\hline & & Order: Legionellales & $\operatorname{TAS}[10,38]$ \\
\hline & & Family: Coxiellaceae & TAS [11] \\
\hline & & Genus: Coxiella & TAS [39] \\
\hline & & Species: Coxiella burnetii & TAS $[7,8,40$ \\
\hline & & Strain: Namibia & NAS \\
\hline & Gram stain & Negative & TAS [14] \\
\hline & Cell shape & Coccobacillary rod & TAS [14] \\
\hline & Motility & None & TAS [14] \\
\hline & Sporulation & $\mathrm{No}^{*}$ & TAS [12] \\
\hline & $\begin{array}{l}\text { Temperature } \\
\text { range }\end{array}$ & $35-37^{\circ} \mathrm{C}$ & TAS [26] \\
\hline & $\begin{array}{l}\text { Optimum } \\
\text { temperature }\end{array}$ & $37^{\circ} \mathrm{C}$ & TAS [26] \\
\hline & $\begin{array}{l}\text { pH range; } \\
\text { Optimum }\end{array}$ & $4.5-5.3 ; 4.5$ & TAS [41] \\
\hline & Carbon source & Glutamate, citrate & $\operatorname{TAS}[42,43]$ \\
\hline MIGS-6 & Habitat & $\begin{array}{l}\text { intracellular, polyhostal } \\
\text { long persistence in the } \\
\text { environment }\end{array}$ & TAS [26] \\
\hline MIGS-6.3 & Salinity & Unknown & NAS \\
\hline MIGS-22 & Oxygen & Microaerophilic (2.5\%) & TAS [26] \\
\hline MIGS-15 & Biotic relationship & Endosymbiont & NAS \\
\hline MIGS-14 & Pathogenicity & highly pathogenic & TAS [44] \\
\hline MIGS-4 & $\begin{array}{l}\text { Geographic } \\
\text { location }\end{array}$ & Windhoek, Namibia & NAS \\
\hline MIGS-5 & Sample collection & 1991 & NAS \\
\hline MIGS-4.1 & Latitude & Unknown & NAS \\
\hline MIGS-4.2 & Longitude & Unknown & NAS \\
\hline MIGS-4.4 & Altitude & Unknown & NAS \\
\hline
\end{tabular}

${ }^{a}$ Evidence codes - IDA: Inferred from Direct Assay; TAS: Traceable Author Statement (i.e., a direct report exists in the literature); NAS: Non-traceable Author Statement (i.e., not directly observed for the living, isolated sample, but based on a generally accepted property for the species, or anecdotal evidence). These evidence codes are from the Gene Ontology project [45]. ${ }^{*}$ A morphological distinct variant with enhanced stability in harsh environmental conditions is described (SCV = small cell variant).

hour. After cooling to room temperature, $100 \mathrm{mM}$ Tris ( $\mathrm{pH} 7.8$ ), $1 \mathrm{mM}$ EDTA, a 15\% sucrose solution, and $1 \mathrm{mg} /$ $\mathrm{ml}$ lysozyme solution (Sigma-Aldrich) were added and the resulting mixture was incubated at $37^{\circ} \mathrm{C}$ for $16 \mathrm{~h}$. On the following day, $100 \mathrm{mM}$ Tris ( $\mathrm{pH}$ 12.0), $1 \mathrm{mM}$ EDTA, and $5 \%$ SDS were added and the sample was incubated at $56^{\circ} \mathrm{C}$ for one hour.
Table 2 Project information

\begin{tabular}{lll}
\hline MIGS ID & Property & Term \\
\hline MIGS-31 & Finishing quality & Improved high-quality draft \\
MIGS-28 & Libraries used & Nextera DNA Sample Prep Kit \\
MIGS-29 & Sequencing platforms & Illumina MiSeq, 2x 150 paired-end \\
MIGS-31.2 & Fold coverage & $91 \times$ \\
MIGS-30 & Assemblers & SPAdes, IDBA \\
MIGS-32 & Gene calling method & Prodigal, GeneMarkS, Glimmer \\
& Locus Tag & CBNA \\
& NCBI Taxonomy ID & 1321945 \\
& Genbank ID & CP007555, CP007556 \\
& Genbank Date of Release & October 16, 2014 \\
& GOLD ID & Gi0055848 \\
& BIOPROJECT & PRJNA197124 \\
& Project relevance & Medical, bioforensic, evolution \\
MIGS-13 & Source Material Identifier & SAMN02045684 \\
\hline & &
\end{tabular}

The sample was then cooled to room temperature and treated with phenol/chloroform twice before three volumes of ice cold $\left(-20^{\circ} \mathrm{C}\right) 99.5 \%$ ethanol to precipitate the DNA were added. After incubation at $-20^{\circ} \mathrm{C}$ for $30 \mathrm{~min}$, the sample was centrifuged at $19,000 \times \mathrm{g}(15,000 \mathrm{rpm})$ for $30 \mathrm{~min}$. The pellet was then resuspended in $1 \times \mathrm{TE}$ containing $50 \mu \mathrm{g}$ RNase (Epicentre, Madison, WI, USA) and incubated at $37^{\circ} \mathrm{C}$ for one hour. Proteinase K (500 $\mu \mathrm{g}$, Epicentre) was then added and the resulting mixture was incubated for another hour at $37^{\circ} \mathrm{C}$. The sample was treated with phenol/chloroform twice before precipitation of the DNA by adding 0.1 volume of $3 \mathrm{M}$ sodium acetate and 2.5 volumes of ice cold $\left(-20^{\circ} \mathrm{C}\right) 99.5 \%$ ethanol. The resulting mixture was then incubated at $-20^{\circ} \mathrm{C}$ for $30 \mathrm{~min}$, centrifuged, and washed twice with $80 \%$ ethanol. After centrifugation the pellet was air dried and resuspended in $1 \times \mathrm{TE}$.

To obtain larger quantities of DNA for whole genome sequencing, the sample was amplified using the MDA kit Illustra GenomePhi V2 Amplification Kit (GE Healthcare Life Sciences and the REPLI-g UltraFast Mini Kit (Qiagen, Hilden, Germany), respectively, according to the manufacturers' instructions. Once the amplification was complete, the enzymes were inactivated by heating the sample to $65^{\circ} \mathrm{C}$. The product was then diluted with sterile distilled water, the DNA was extracted using phenol/ chloroform, and the product was precipitated using 0.1 volumes of $3 \mathrm{M}$ sodium acetate and 2.5 volumes of ice cold $\left(-20^{\circ} \mathrm{C}\right) 99.5 \%$ ethanol followed by incubation for $16 \mathrm{~h}$ at $-20^{\circ} \mathrm{C}$. The precipitated sample was centrifuged at $19,000 \times \mathrm{g}(15,000 \mathrm{rpm})$ for 30 minutes at $4^{\circ} \mathrm{C}$, washed once with $70 \%$ ethanol and air dried. The pellet was then dissolved in $1 \times \mathrm{TE}$ and the DNA concentration was estimated using a Qubit fluorometer (Life Technologies, Carlsbad, CA, USA). 
Table 3 Summary of genome: one chromosome and one plasmid

\begin{tabular}{lcll}
\hline Label & Size $\mathbf{( M b )}$ & Topology & INSDC identifier \\
\hline Chromosome & 2.06 & circular & CP007555 \\
Plasmid & 0.04 & circular & CP007556 \\
\hline
\end{tabular}

\section{Genome sequencing and assembly}

The isolated DNA was prepared using the Nextera DNA Sample Prep Kit (Illumina, Hayward, CA, USA) and paired-end reads of $150 \mathrm{bp}$ were sequenced on a MiSeq benchtop sequencer (Illumina) at the Swedish Defence Research Agency and according to the manufacturer's instructions.

The sequenced reads were filtered against the draft genome assembly of Chlorocebus sabaeus (assembly AQIB01), Macaca mulatta (assembly AANU01), and Papio anubis (assembly AHZZ01) as well as four bacterial contaminants: Escherichia coli str. K-12 substr. MG1655 (NC_000913), Mycoplasma arginini 7264 (NZ_AORG01000000), Propionibacterium acnes 6609 (NC_017535) and Streptococcus suis SC84 (NC_012924) using mirabait, a kmer-based read mapping tool [47]. Afterwards, bacterial contaminant reads were blasted against the C. burnetii RefSeq genomes and the contaminant genomes. Reads which are more similar in their full length to C. burnetii were reintegrated into the filtered read set. This step was done as a quality control not to filter too many reads, such as reads mapping to orthologous genes or the ribosomal RNA operon.

Afterwards we used MIRA [47] to quality trim the reads and aligned them to the closest strain Q154 [48]. The raw coverage at this stage was $120 \times$. Then, we used

Table 4 Genome statistics

\begin{tabular}{lrr}
\hline Attribute & Value & \% of Total $^{\mathbf{a}}$ \\
\hline Genome size (bp) & $2,101,438$ & 100.00 \\
DNA coding (bp) & $1,788,283$ & 82.88 \\
DNA G + C (bp) & 865,056 & 41.16 \\
DNA scaffolds & 2 & 100.00 \\
Total genes & 2,030 & 100.00 \\
Protein coding genes & 1,979 & 97.49 \\
RNA genes & 51 & 2.51 \\
Pseudo genes & 98 & 4.83 \\
Genes in internal clusters & 21 & 1.03 \\
Genes with function prediction & 1,309 & 66.14 \\
Genes assigned to COGs & 1,294 & 65.39 \\
Genes with Pfam domains & 1,424 & 71.96 \\
Genes with signal peptides & 263 & 13.29 \\
Genes with transmembrane helices & 473 & 23.90 \\
CRISPR repeats & NA & \\
\hline
\end{tabular}

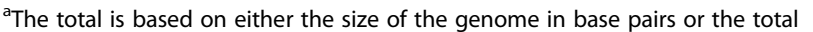
number of protein coding genes in the annotated genome.
BayesHammer [49] to correct the Illumina reads followed by COPE [50] to merge overlapping reads (about 18\%). The resulting merged and unmerged paired-end reads were assembled using Velvet-SC [51], SPAdes [52] and IDBA-UD [53], three assemblers optimized for single-cell sequence data with unequal coverage. Finally, we used GAM-NGS [54] to merge the contigs of the resulting assemblies. During the whole assembly process we used QUAST [55] to find the optimal parameters to obtain as few contigs as possible with the least number of misassemblies and InDels and the greatest N50 value. Afterwards, we used Mauve [56] to predict the order and orientation of the contigs corresponding to Q154.

A close inspection of the contig boundaries revealed many a lot of chimeric sequences, especially at nearly all of the possible IS1111 insertion sequence [57] sites. The reason for this frequent chimera formation can be explained by circular intermediates of IS1111 (although their presence in Nine Mile could not be detected by

Table 5 Number of genes associated with general COG functional categories

\begin{tabular}{|c|c|c|c|}
\hline Code & Value & $\%$ age & Description \\
\hline J & 135 & 6.82 & Translation, ribosomal structure and biogenesis \\
\hline A & 1 & 0.05 & RNA processing and modification \\
\hline K & 50 & 2.53 & Transcription \\
\hline L & 90 & 4.55 & Replication, recombination and repair \\
\hline B & 0 & 0.00 & Chromatin structure and dynamics \\
\hline D & 28 & 1.41 & $\begin{array}{l}\text { Cell cycle control, Cell division, chromosome } \\
\text { partitioning }\end{array}$ \\
\hline V & 23 & 1.16 & Defense mechanisms \\
\hline $\mathrm{T}$ & 40 & 2.02 & Signal transduction mechanisms \\
\hline M & 120 & 6.06 & Cell wall/membrane biogenesis \\
\hline $\mathrm{N}$ & 12 & 0.61 & Cell motility \\
\hline U & 37 & 1.87 & Intracellular trafficking and secretion \\
\hline $\mathrm{O}$ & 59 & 2.98 & $\begin{array}{l}\text { Posttranslational modification, protein } \\
\text { turnover, chaperones }\end{array}$ \\
\hline C & 89 & 4.50 & Energy production and conversion \\
\hline G & 74 & 3.74 & Carbohydrate transport and metabolism \\
\hline $\mathrm{E}$ & 105 & 5.31 & Amino acid transport and metabolism \\
\hline $\mathrm{F}$ & 46 & 2.32 & Nucleotide transport and metabolism \\
\hline $\mathrm{H}$ & 93 & 4.70 & Coenzyme transport and metabolism \\
\hline 1 & 62 & 3.13 & Lipid transport and metabolism \\
\hline$P$ & 47 & 2.37 & Inorganic ion transport and metabolism \\
\hline Q & 32 & 1.62 & $\begin{array}{l}\text { Secondary metabolites biosynthesis, } \\
\text { transport and catabolism }\end{array}$ \\
\hline $\mathrm{R}$ & 155 & 7.83 & General function prediction only \\
\hline S & 104 & 5.26 & Function unknown \\
\hline - & 685 & 34.61 & Not in COGs \\
\hline
\end{tabular}

The total is based on the total number of protein coding genes in the genome. 


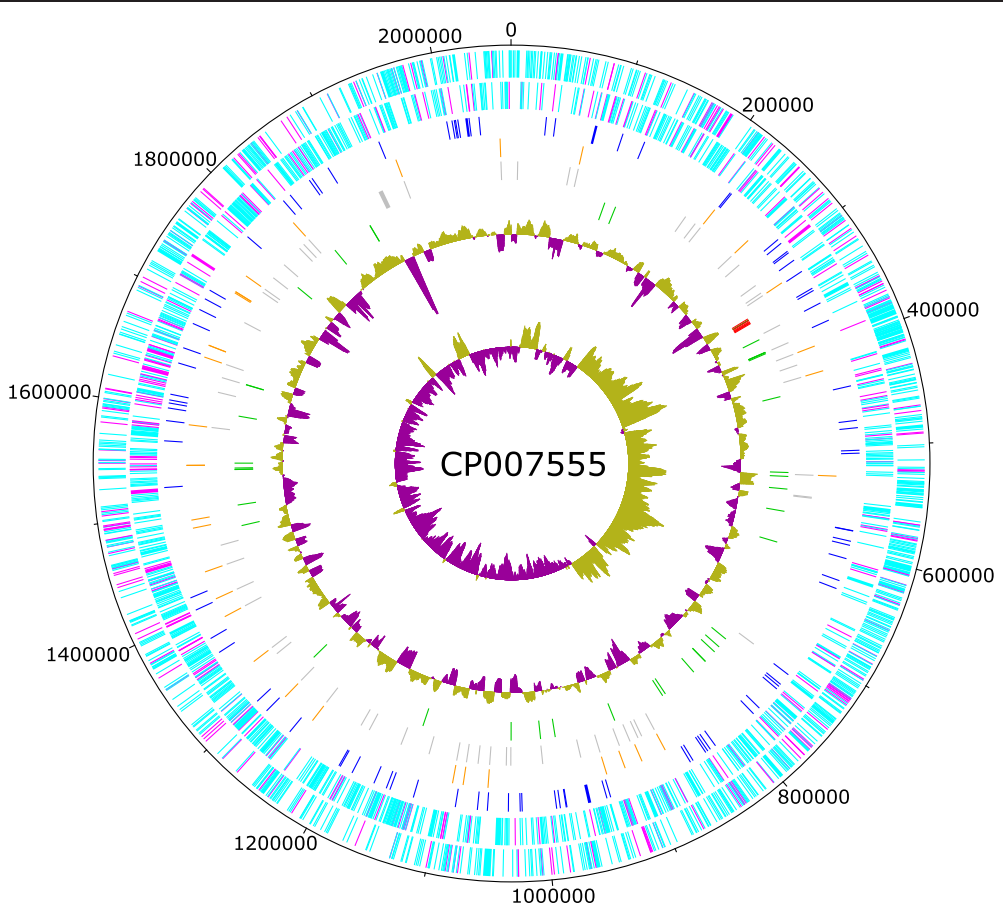

Figure 3 Graphical circular map of the chromosome. From outside to the center: Genes on forward strand (color by 'with function prediction' turquoise or hypothetical magenta), Genes on reverse strand (color scheme is the same as on forward strand), pseudogenes (blue), insertion elements (orange), gaps (gray), RNA genes (tRNAs green, rRNAs red), GC content, GC skew.

PCR, maybe caused by low expression level of these transposases) in combination with the whole genome amplification technique applied here [58,59].

We used Cutadapt [60] to trim IS1111 sequences from the 5 ' and 3 ' end of the assembled contigs to avoid mis-

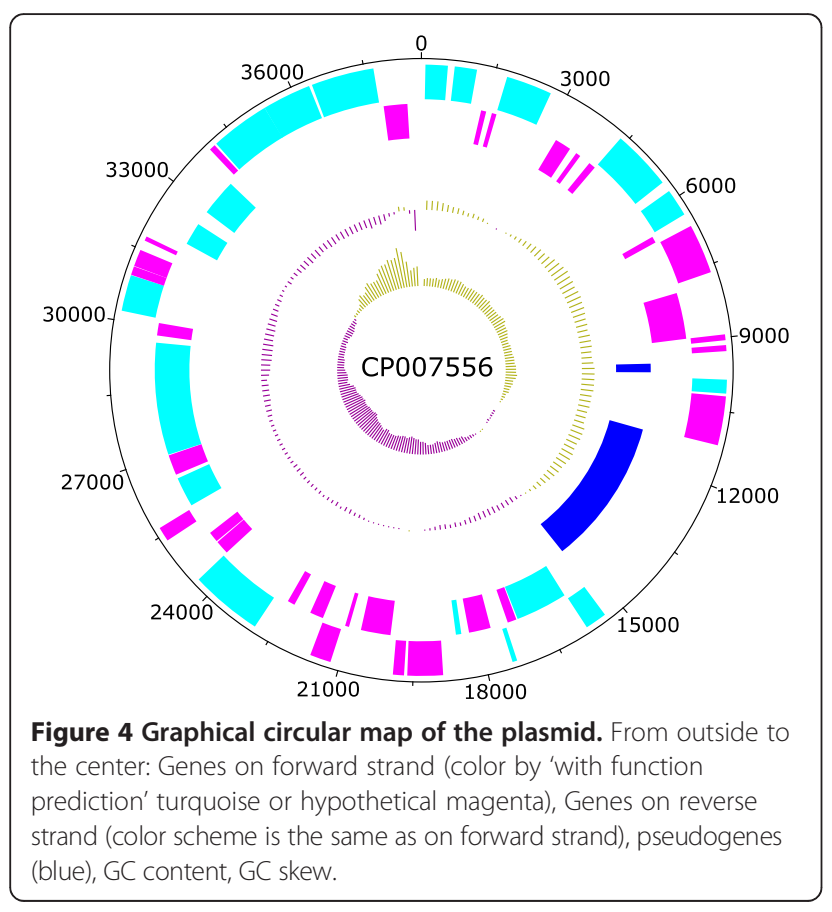

scaffolding and artificial gap filling. Afterwards, we used Opera [61] and information from our extended IS1111 typing method (manuscript in preparation) to scaffold the contigs semi-automatically. Then we used GapFiller [62] to close or reduce gaps. All insertion sequences sites (including IS1111, IS30 and ISAs1) were verified again to avoid false positive insertions and to fill in missing sequences with Ns.

\section{Genome annotation}

Gene calling and functional annotation was performed using the PEDANT system [63]. Briefly, genes were called using Prodigal [64], Glimmer [65] and GeneMarkS [66]; all had been trained on the five RefSeq complete C. burnetii genomes. Consensus gene models were created by majority, domain or structural annotations in alternative start regions or preferring the Prodigal model. Structural RNAs were predicted using RNAmmer [67] (rRNAs), tRNAscanSE [68] and similarity to Rfam [69]. The known 23S rRNA intervening sequence (IVS) [70] and the two self-splicing group I introns [71] were annotated manually. Protein similarities and InterPro domain annotations were obtained from SIMAP [72] if possible or computed locally. Similarities to SCOP [73] and KEGG [74] were computed using BLAST [30]. Signal peptides were predicted using SignalP [75], transmembrane proteins using TMHMM [76]. Gene names and protein descriptions were annotated 
by a combination of a stringent similarity search against the UniProtKB/Swiss-Prot database [77] as well as using BLANNOTATOR [78] followed by manual curation. The genome and its functional annotation can be browsed at the PEDANT website [79].

\section{Genome properties}

The C. burnetii Namibia genome has a total size of about $2,101,438$ bp (41.1\% GC content), with one circular chromosome of about 2,062,778 bp (containing 61 gaps with an estimated total gap length of $66,246 \mathrm{bp}$ ) and one plasmid of 38,660 bp. For the chromosome and plasmid, 2,030 genes were predicted, 1,979 of which are proteincoding genes. 1,309 of protein coding genes were assigned to a putative function with the remaining annotated as hypothetical proteins. 21 protein coding genes belong to 9 paralogous families in this genome corresponding to a gene content redundancy of $0.9 \%$, mainly caused by the high number of transposases. The properties and the statistics of the genome are summarized in Tables 3, 4 and 5 and a circular map of the chromosome and plasmid is shown in Figures 3 and 4.

\section{Insights from the genome sequence}

A whole genome comparison with all five complete reference genomes (accessions: NC_009727, NC_010117, NC_002971, NC_011528, NC_011527) revealed strain Q154 as the most similar strain. In silico typing of strain Namibia showed the same adaA deletion variant 1 [80], but Multispacer Sequence Typing (MST) and Multiplelocus variable-number of tandem repeat (VNTR) analysis (MLVA) generated different profiles compared to Q154 (30 vs. 8 and D16 vs. D6 respectively) [46,81].

The COG distribution is quite similar, except fewer annotated proteins in Q154, likely because of older gene prediction algorithms. The tRNA composition is identical in both strains. At the nucleotide level 2,767 chromosomal SNPs and 77 plasmid-related SNPs were found (752 intergenic, 5 non-coding and 2,087 within coding regions). Further, there is a $6 \mathrm{~kb}$ region in the Namibia genome which is not present in the Q154/Q177 clade (Figure 2) but in the other complete reference strains. It contains the ankyrin repeat protein AnkI (CBNA_1063). Also, a $4.5 \mathrm{~kb}$ region present in Q154 (containing an acetyltransferase, CbuK_0095 and a bacterial regulatory protein, CbuK_0101) is absent in Namibia. Large structural variations were not detected.

\section{Conclusion}

We present the first whole genome sequence of Coxiella burnetii strain Namibia from Africa with its distinct genotype and unique genomic features and regions. We describe a combined set of laboratory methods and bioinformatics tools that resulted in a high quality whole genome sequence of this strain. The applied bioinformatics approach accounts for potential problems caused by the MDA/WGA method such as uneven sequence coverage and artificial products like chimeric reads. The sequencing and assembly pipeline presented here is suggested as a standard when sequencing of C. burnetii strains is done with or without the application of whole genome amplification methods. The incorporation of insertion sequence typing data can help to reduce the number of scaffolds down to a single whole genome sequence and avoids creating and sequencing an additional long distance mate-pair library usually needed to scaffold highly repetitive genomes.

To speed up the sequencing of new C. burnetii strains and to overcome the problems in generating high quality genomes, a joint research project with the Swedish Defence Institute (FOI) in Umeå was established: The Coxiella Genome Sequencing Consortium (CGSC) [82].

\section{Abbreviations}

WGA: Whole genome amplification; MDA: Multiple displacement amplification; BGM: Buffalo Green Monkey.

\section{Competing interests}

The authors declare that they have no competing interests.

\section{Authors' contributions}

MB, AM performed the microbiology and molecular biology studies; CÖ KM performed the sequencing; MCW performed the annotation and genomic analysis; DF provided strain material; AS, PL, MF, DF, MCW wrote the manuscript. All authors read and approved the final manuscript.

\section{Acknowledgements}

This work was supported in part by the German Ministry of Education and Research (BMBF) under contract No. 01KI1001.

We would like to thank Heike Gehringer for critical reading and useful discussion of the manuscript.

\section{Author details}

${ }^{1}$ Institute of Bioinformatics and Systems Biology, Helmholtz Zentrum München, German Research Center for Environmental Health, Neuherberg, Germany. ${ }^{2}$ Department of Genome-Oriented Bioinformatics, Center of Life and Food Science Weihenstephan, Technische Universität München, Freising, Germany. ${ }^{3}$ CBRN Defence and Security, Swedish Defence Research Agency (FOI), Umeå, Sweden. ${ }^{4}$ Bundeswehr Institute of Microbiology (BwIM), Munich, Germany.

Received: 19 May 2014 Accepted: 17 November 2014

Published: 29 December 2014

\section{References}

1. Beare PA, Howe D, Cockrell DC, Heinzen RA. Efficient method of cloning the obligate intracellular bacterium Coxiella burnetii. Appl Env Microbiol. 2007; 73:4048-54.

2. Klee SR, Tyczka J, Ellerbrok H, Franz T, Linke S, Baljer G, Appel B. Highly sensitive real-time PCR for specific detection and quantification of Coxiella burnetii. BMC Microbiol. 2006; 6:2

3. Raghunathan A, Ferguson HR Jr, Bornarth CJ, Song W, Driscoll M, Lasken RS. Genomic DNA amplification from a single bacterium. App/ Env Microbiol. 2005; 71:3342-7.

4. Rodrigue S, Malmstrom RR, Berlin AM, Birren BW, Henn MR, Chisholm SW. Whole genome amplification and de novo assembly of single bacterial cells. PLoS One. 2009; 4:e6864.

5. Lage JM, Leamon JH, Pejovic T, Hamann S, Lacey M, Dillon D, Segraves R, Vossbrinck B, González A, Pinkel D, Albertson DG, Costa J, Lizardi PM. Whole genome analysis of genetic alterations in small DNA samples using 
hyperbranched strand displacement amplification and array-CGH Genome Res. 2003: 13:294-307.

6. Kumar S, Gangoliya SR, Berri M, Rodolakis A, Alam SI. Whole genome amplification of the obligate intracellular pathogen Coxiella burneti using multiple displacement amplification. J Microbiol Methods. 2013; 95:368-72.

7. Burnet FM, Freeman $M$, others. Experimental Studies on the Virus of " $Q$ " Fever. Med J Aust. 1937: 2:299-305.

8. Davis GE, Cox HR. Public Health Weekly Reports for DECEMBER 30, 1938. Public Health Rep. 1938; 53:2259-309.

9. Giménez DF. Staining Rickettsiae in Yolk-Sac Cultures. Stain Technol. 1964 39:135-40.

10. Weisburg WG, Dobson ME, Samuel JE, Dasch GA, Mallavia LP, Baca O, Mandelco L, Sechrest JE, Weiss E, Woese CR. Phylogenetic diversity of the Rickettsiae. J Bacteriol. 1989; 171:4202-6.

11. Garrity GM, Bell JA, Lilburn T. Family II. Coxiellaceae. In: Brenner D, Krieg N, Staley J, Garrity G, Boone D, Vos P, Goodfellow M, Rainey F, Schleifer K-H, editors. Bergey's Man Syst Bacteriol. Volume 2. 2nd ed. New York: Springer; 2005: p. 237.

12. Hanczaruk M, Cutler SJ, Toman R, Frangoulidis D. BSL3 and BSL4 Agents: Epidemiology, Microbiology, and Practical Guidelines. In: Elschner MC, Cutler SJ, Weidmann M, Butaye P, editors. BSL3 BSL4 Agents. Weinheim: Wiley-VCH Verlag GmbH \& Co. KGaA; 2012: p. 57-69.

13. Babudieri B. Q fever: a zoonosis. Adv Vet Sci. 1959; 5:82-182.

14. Maurin M, Raoult D. Q fever. Clin Microbiol Rev. 1999; 12:518-53.

15. Benenson AS, Tigertt WD. Studies on Q fever in man. Trans Assoc Am Physicians. 1956; 69:98-104.

16. Tissot-Dupont H, Torres S, Nezri M, Raoult D. Hyperendemic focus of Q fever related to sheep and wind. Am J Epidemiol. 1999; 150:67-74.

17. Williams JC. Q fever: the biology of Coxiella burnetii. In: Williams JC Thompson HA, editors. Boca Raton: CRC Press; 1991: p. 21-71 [vol. 2]

18. Willems $H$, Ritter $M$, Jäger $C$, Thiele D. Plasmid-homologous sequences in the chromosome of plasmidless Coxiella burnetii Scurry Q217. J Bacteriol. 1997; 179:3293-7.

19. Lautenschläger $S$, Willems $H$, Jäger C, Baljer $G$. Sequencing and characterization of the cryptic plasmid QpRS from Coxiella burnetii. Plasmid. 2000; 44:85-8.

20. Jäger $C$, Lautenschläger $S$, Willems $H$, Baljer G. Coxiella burnetii plasmid types QpDG and QpH1 are closely related and likely identical. Vet Microbiol. 2002; 89:161-6.

21. Thiele $D$, Willems $H$, Haas $M$, Krauss $H$. Analysis of the entire nucleotide sequence of the cryptic plasmid QpH1 from Coxiella burnetii. Eur J Epidemiol. 1994; 10:413-20.

22. Valková D, Kazár J. A new plasmid (QpDV) common to Coxiella burnetii isolates associated with acute and chronic Q fever. FEMS Microbiol Lett. 1995; 125:275-80.

23. Thiele $\mathrm{D}$, Willems $\mathrm{H}$. Is plasmid based differentiation of Coxiella burnetii in "acute" and "chronic" isolates still valid? Eur J Epidemiol. 1994; 10:427-34.

24. Ormsbee RA. The growth of Coxiella burnetii in embryonated eggs. J Bacteriol. 1952; 63:73-86.

25. Gil-Grande R, Aguado JM, Pastor C, García-Bravo M, Gómez-Pellico C, Soriano F, Noriega AR. Conventional viral cultures and shell vial assay for diagnosis of apparently culture-negative Coxiella burnetii endocarditis. Eur J Clin Microbiol Infect Dis. 1995; 14:64-7.

26. Omsland A, Cockrell DC, Howe D, Fischer ER, Virtaneva K, Sturdevant DE, Porcella SF, Heinzen RA. Host cell-free growth of the $Q$ fever bacterium Coxiella burnetii. Proc Natl Acad Sci U S A. 2009; 106:4430-4.

27. Talavera G, Castresana J. Improvement of phylogenies after removing divergent and ambiguously aligned blocks from protein sequence alignments. Syst Biol. 2007; 56:564-77.

28. Paradis E, Claude J, Strimmer K. APE: Analyses of Phylogenetics and Evolution in R language. Bioinformatics. 2004; 20:289-90

29. Schliep KP. phangorn: phylogenetic analysis in R. Bioinformatics. 2011; 27:592-3.

30. Altschul SF, Gish W, Miller W, Myers EW, Lipman DJ. Basic local alignment search tool. J Mol Biol. 1990; 215:403-10.

31. N. C. B. I Resource Coordinators. Database resources of the National Center for Biotechnology Information. Nucleic Acids Res. 2013; 41(Database issue):D8-20.

32. Muyzer G, Sorokin DY, Mavromatis K, Lapidus A, Clum A, Ivanova N, Pati A, d' Haeseleer P, Woyke T, Kyrpides NC. Complete genome sequence of Thioalkalivibrio sulfidophilus HL-EbGr7. Stand Genomic Sci. 2011; 4:23-35.
33. Field D, Garrity G, Gray T, Morrison N, Selengut J, Sterk P, Tatusova T, Thomson N, Allen MJ, Angiuoli SV, Ashburner M, Axelrod N, Baldauf S, Ballard S, Boore J, Cochrane G, Cole J, Dawyndt P, De Vos P, DePamphilis C, Edwards R, Faruque N, Feldman R, Gilbert J, Gilna P, Glöckner FO, Goldstein P, Guralnick R, Haft D, Hancock D, et al. The minimum information about a genome sequence (MIGS) specification. Nat Biotechnol. 2008; 26:541-7.

34. Woese CR, Kandler O, Wheelis ML. Towards a natural system of organisms: proposal for the domains Archaea, Bacteria, and Eucarya. Proc Natl Acad Sci U S A. 1990; 87:4576-9.

35. Garrity GM, Bell JA, Lilburn T. Phylum XIV. Proteobacteria. In: Brenner D, Krieg N, Staley J, Garrity G, Boone D, Vos P, Goodfellow M, Rainey F, Schleifer K-H, editors. Bergey's Man Syst Bacteriol. Volume 2. 2nd ed. New York: Springer; 2005: p. 1.

36. Garrity GM, Bell JA, Lilburn T. Class III. Gammaproteobacteria. In: Brenner D, Krieg N, Staley J, Garrity G, Boone D, Vos P, Goodfellow M, Rainey F, Schleifer K-H, editors. Bergey's Man Syst Bacteriol. Volume 2. 2nd ed. New York: Springer; 2005: p. 1.

37. Euzéby J. Validation of publication of new names and new combinations previously effectively published outside the IJSEM. Int J Syst Evol Microbiol. 2005; 55:2235-8.

38. Garrity GM, Bell JA, Lilburn T. Order VI. Legionellales. In: Brenner D, Krieg N, Staley J, Garrity G, Boone D, Vos P, Goodfellow M, Rainey F, Schleifer K-H editors. Bergey's Man Syst Bacteriol. Volume 2. 2nd ed. New York: Springer; 2005: p. 210-47.

39. Philip CB. Coxiella. Am J Hyg. 1943; 37:301-9.

40. Skerman VBD, McGOWAN V, Sneath PHA. Approved lists of bacterial names. Int J Syst Bacteriol. 1980; 30:225-30.

41. Hackstadt T, Williams JC. Biochemical stratagem for obligate parasitism of eukaryotic cells by Coxiella burnetii. Proc Natl Acad Sci U S A. 1981; 78:3240-4.

42. Hackstadt T, Williams JC. pH dependence of the Coxiella burnetii glutamate transport system. J Bacteriol. 1983; 154:598-603.

43. Omsland A, Cockrell DC, Fischer ER, Heinzen RA. Sustained Axenic Metabolic Activity by the Obligate Intracellular Bacterium Coxiella burnetii. J Bacteriol. 2008; 190:3203-12.

44. Tigertt WD, Benenson AS, Gochenour WS. Airborne Q Fever. Bacterio/ Rev. 1961; 25:285-93.

45. Ashburner M, Ball CA, Blake JA, Botstein D, Butler H, Cherry JM, Davis AP, Dolinski K, Dwight SS, Eppig JT, Harris MA, Hill DP, Issel-Tarver L, Kasarskis A, Lewis S, Matese JC, Richardson JE, Ringwald M, Rubin GM, Sherlock G. Gene ontology: tool for the unification of biology. The Gene Ontology Consortium. Nat Genet. 2000; 25:25-9.

46. Karlsson E, Macellaro A, Byström M, Forsman M, Frangoulidis D, Janse I, Larsson P, Lindgren P, Ohrman C, van Rotterdam B, Sjödin A, Myrtennäs K. Eight New Genomes and Synthetic Controls Increase the Accessibility of Rapid MeltMAMA SNP Typing of Coxiella burnetii. PLoS One. 2014; 9:e85417.

47. Chevreux B, Wetter T, Suhai S. Genome Sequence Assembly Using Trace Signals and Additional Sequence Information. In: Computer Science and Biology: Proceedings of the German Conference on Bioinformatics GCB ' 99 ; October 4 - 6, 1999, Hannover, Germany. Hannover: GBF-Braunschweig, Department of Bioinformatics; 1999: p. 45-56.

48. Beare PA, Unsworth N, Andoh M, Voth DE, Omsland A, Gilk SD, Williams KP, Sobral BW, Kupko JJ, Porcella SF, Samuel JE, Heinzen RA. Comparative genomics reveal extensive transposon-mediated genomic plasticity and diversity among potential effector proteins within the genus Coxiella. Infect Immun. 2009; 77:642-56.

49. Nikolenko SI, Korobeynikov Al, Alekseyev MA. BayesHammer: Bayesian clustering for error correction in single-cell sequencing. BMC Genomics. 2013; 14:S7.

50. Liu B, Yuan J, Yiu S-M, Li Z, Xie Y, Chen Y, Shi Y, Zhang H, Li Y, Lam T-W, Luo R. COPE: an accurate k-mer-based pair-end reads connection tool to facilitate genome assembly. Bioinformatics. 2012; 28:2870-4.

51. Chitsaz H, Yee-Greenbaum JL, Tesler G, Lombardo M-J, Dupont CL, Badger JH, Novotny M, Rusch DB, Fraser LJ, Gormley NA, Schulz-Trieglaff O, Smith GP, Evers DJ, Pevzner PA, Lasken RS. Efficient de novo assembly of single-cell bacterial genomes from short-read data sets. Nat Biotechnol. 2011; 29:915-21.

52. Bankevich A, Nurk S, Antipov D, Gurevich AA, Dvorkin M, Kulikov AS, Lesin VM, Nikolenko SI, Pham S, Prjibelski AD, Pyshkin AV, Sirotkin AV, Vyahhi N, Tesler G, Alekseyev MA, Pevzner PA. SPAdes: a new genome assembly algorithm and its applications to single-cell sequencing. J Comput Biol. 2012; 19:455-77. 
53. Peng Y, Leung HCM, Yiu SM, Chin FYL. IDBA-UD: a de novo assembler for single-cell and metagenomic sequencing data with highly uneven depth. Bioinformatics. 2012; 28:1420-8.

54. Vicedomini R, Vezzi F, Scalabrin S, Arvestad L, Policriti A. GAM-NGS: genomic assemblies merger for next generation sequencing. BMC Bioinformatics. 2013; 14 Suppl 7:S6.

55. Gurevich A, Saveliev V, Vyahhi N, Tesler G. QUAST: quality assessment tool for genome assemblies. Bioinformatics. 2013; 29:1072-5.

56. Rissman Al, Mau B, Biehl BS, Darling AE, Glasner JD, Perna NT. Reordering contigs of draft genomes using the Mauve aligner. Bioinformatics. 2009; 25:2071-3.

57. Partridge SR, Hall RM. The IS1111 family members IS4321 and IS5075 have subterminal inverted repeats and target the terminal inverted repeats of Tn21 family transposons. J Bacteriol. 2003; 185:6371-84.

58. Denison AM, Thompson HA, Massung RF. IS1111 insertion sequences of Coxiella burnetii: characterization and use for repetitive element PCR-based differentiation of Coxiella burnetii isolates. BMC Microbiol. 2007; 7:91.

59. Lasken RS, Stockwell TB. Mechanism of chimera formation during the Multiple Displacement Amplification reaction. BMC Biotechnol. 2007; 7:19.

60. Martin M. Cutadapt removes adapter sequences from high-throughput sequencing reads. EMBnetjournal. 2011; 17:10-12.

61. Gao S, Sung W-K, Nagarajan N. Opera: reconstructing optimal genomic scaffolds with high-throughput paired-end sequences. J Comput Biol. 2011; 18:1681-91.

62. Boetzer M, Pirovano W. Toward almost closed genomes with GapFiller. Genome Biol. 2012; 13:R56.

63. Walter MC, Rattei T, Arnold R, Güldener U, Münsterkötter M, Nenova K Kastenmüller G, Tischler P, Wölling A, Volz A, Pongratz N, Jost R, Mewes H-W, Frishman D. PEDANT covers all complete RefSeq genomes. Nucleic Acids Res. 2009; 37(Database issue):D408-11.

64. Hyatt D, Chen G-L, Locascio PF, Land ML, Larimer FW, Hauser LJ. Prodigal: prokaryotic gene recognition and translation initiation site identification. BMC Bioinformatics. 2010; 11:119.

65. Delcher AL, Bratke KA, Powers EC, Salzberg SL. Identifying bacterial genes and endosymbiont DNA with Glimmer. Bioinformatics. 2007; 23:673-9.

66. Besemer J, Lomsadze A, Borodovsky M. GeneMarkS: a self-training method for prediction of gene starts in microbial genomes. Implications for finding sequence motifs in regulatory regions. Nucleic Acids Res. 2001; 29:2607-18.

67. Lagesen $\mathrm{K}$, Hallin $\mathrm{P}$, Rødland EA, Staerfeldt H-H, Rognes $\mathrm{T}$, Ussery DW. RNAmmer: consistent and rapid annotation of ribosomal RNA genes. Nucleic Acids Res. 2007; 35:3100-8.

68. Lowe TM, Eddy SR. tRNAscan-SE: a program for improved detection of transfer RNA genes in genomic sequence. Nucleic Acids Res. 1997; 25:955-64.

69. Burge SW, Daub J, Eberhardt R, Tate J, Barquist L, Nawrocki EP, Eddy SR, Gardner PP, Bateman A. Rfam 11.0: 10 years of RNA families. Nucleic Acids Res. 2013; 41(Database issue):D226-32.

70. Afseth G, Mo YY, Mallavia LP. Characterization of the 23S and 5S rRNA genes of Coxiella burnetii and identification of an intervening sequence within the 23S rRNA gene. J Bacteriol. 1995; 177:2946-9.

71. Raghavan R, Miller SR, Hicks LD, Minnick MF. The unusual 23S rRNA gene of Coxiella burnetii: two self-splicing group I introns flank a 34-base-pair exon, and one element lacks the canonical $\Omega$ G. J Bacterio/ 2007, 189:6572-6579.

72. Arnold R, Goldenberg F, Mewes H-W, Rattei T. SIMAP-the database of all-against-all protein sequence similarities and annotations with new interfaces and increased coverage. Nucleic Acids Res. 2014; 42(Database issue):D279-84.

73. Andreeva A, Howorth D, Brenner SE, Hubbard TJP, Chothia C, Murzin AG. SCOP database in 2004: refinements integrate structure and sequence family data. Nucleic Acids Res. 2004; 32(Database issue):D226-9.

74. Kanehisa M, Goto S, Sato Y, Kawashima M, Furumichi M, Tanabe M. Data, information, knowledge and principle: back to metabolism in KEGG. Nucleic Acids Res. 2014; 42(Database issue):D199-205

75. Bendtsen JD, Nielsen H, Heijne G, Von Brunak S. Improved prediction of signal peptides: SignalP 3.0. J Mol Biol. 2004; 340:783-95.

76. Krogh A, Larsson B, von Heijne G, Sonnhammer EL. Predicting transmembrane protein topology with a hidden Markov model: application to complete genomes. J Mol Biol. 2001; 305:567-80.
77. Consortium UP. Activities at the Universal Protein Resource (UniProt). Nucleic Acids Res. 2014; 42(Database issue):D191-8.

78. Kankainen M, Ojala T, Holm L. BLANNOTATOR: enhanced homology-based function prediction of bacterial proteins. BMC Bioinformatics. 2012; 13:33.

79. PEDANT: C. burnetii str. Namibia Genome. [http://pedant.helmholtzmuenchen.de/bioproject/197124]

80. Frangoulidis D, Splettstoesser WD, Landt O, Dehnhardt J, Henning K, Hilbert A, Bauer T, Antwerpen M, Meyer H, Walter MC, Knobloch JK-M. Microevolution of the Chromosomal Region of Acute Disease Antigen A ( $a d a A)$ in the Query (Q) Fever Agent Coxiella burnetii. PLoS One. 2013; 8:e53440.

81. Glazunova O, Roux V, Freylikman O, Sekeyova Z, Fournous G, Tyczka J, Tokarevich N, Kovacova E, Marrie TJ, Raoult D. Coxiella burnetii Genotyping. Emerg Infect Dis. 2005; 11:1211-7.

82. The Coxiella Genome Sequencing Consortium (CGSC). [http://coxiella.net]

doi:10.1186/1944-3277-9-22

Cite this article as: Walter et al:: Genome sequence of Coxiella burnetii strain Namibia. Standards in Genomic Sciences 2014 9:22.

\section{Submit your next manuscript to BioMed Central and take full advantage of:}

- Convenient online submission

- Thorough peer review

- No space constraints or color figure charges

- Immediate publication on acceptance

- Inclusion in PubMed, CAS, Scopus and Google Scholar

- Research which is freely available for redistribution 